\title{
METODE DAKWAH MENURUT JALALUDDIN RAKHMAT DAN IMPLEMENTASINYA DALAM BIMBINGAN DAN KONSELING ISLAM (BKI)
}

\author{
Sri Maullasari \\ PKBI Kota Semarang \\ Email: maullasari174@gmail.com
}

\begin{abstract}
In line with the increasingly rapid development of the era, da'wah activities require a precise strategy and a clear concept. For this reason, it is necessary to have a systematic method or method that is used to deliver material or preach messages to mad'u. The author focuses on conducting studies between the methods of da'wah according to Jalaluddin Rakhmat and their implementation in Islamic guidance and counseling because they can be said to be interrelated. According to Jalaluddin Rachmat there are three methods of da'wah, namely: preaching with wisdom (bi al-hikmah), mau'idzah hasanah, and da'wah with good discussion (mujadalah billati hiya ahsan). The da'wah method according to Jalaluddin Rakhmat can be implemented in the guidance and counseling process as an effort to deepen the application of counseling communication skills. Al hikmah can be applied in the initial stages of counseling process trying to understand a client's problems. Mauidzhah hasanah can be applied in the middle stage, which is the stage of work where there will be advice so that clients can find various alternatives to the problems at hand. Mujadalah billati hiya ahsan can be applied in the final stage, namely the action stage which seeks to convince clients of solutions that will be taken independently.
\end{abstract}

Sejalan dengan perkembangan zaman yang semakin pesat, kegiatan dakwah memerlukan sebuah strategi yang jitu dan konsep yang jelas. Untuk itu perlu sebuah metode atau cara yang sistematis yang digunakan untuk menyampaikan materi atau pesan dakwah kepada mad'u. Dalam kajian ini penulis fokus untuk melakukan pengkajian antara metode dakwah menurut Jalaluddin Rakhmat dan implementasinya dalam bimbingan dan konseling Islam karena keduanya bisa dikatakan saling berkaitan. Menurut Jalaluddin Rakhmat terdapat tiga metode dakwah, yakni, dakwah dengan hikmah (bi al-hikmah), mau'idzah hasanah, dan dakwah dengan diskusi yang baik (mujadalah billati hiya ahsan). Metode dakwah menurut Jalaluddin Rakhmat dapat diimplementasikan dalam proses bimbingan dan konseling sebagai upaya memperdalam penerapan ketrampilan komunikasi konseling. Al-hikmah dapat diterapkan dalam tahap awal konseling, untuk memahami suatu permasalahan klien. Mauidzhah hasanah dapat diterapkan dalam tahap pertengahan, yang merupakan tahap kerja dimana akan adanya nasihat-nasihat agar klien bisa menemukan berbagai alternatif atas permasalahan yang dihadapi. Mujadalah billati hiya ahsan dapat diterapkan dalam tahap akhir, yaitu tahap tindakan (action) yang berusaha untuk menyakinkan klien terhadap solusi yang akan diambil secara mandiri.

Kata Kunci : Metode dakwah, Bimbingan dan Konseling Islam 


\section{A. PENDAHULUAN}

Era globalisasi yang dahsyat telah memberikan dampak bagi kehidupan manusia. Salah satunya adalah dalam lingkup dakwah Islam.Pada era ini secara sadar maupun tidak umat manusia dihadapkan pada pilihan-pilihan. Pada satu sisi pilihan tersebut akan membawa hikmah dan manfaat bagi kehidupan dirinya, tetapi di sisi lain akan memberikan mudharat dan kesengsaraan. Pada masa ini seakan tidak bisa dibendung lajunya permasalahan ummat, karena telah memasuki setiap sudut negara sehingga menjadi problem yang sangat besar pagi para da'i. Persoalan yang dihadapi sekarang adalah tantangan dakwah yang semakin berat dan penerapan metode dakwah yang belum tepat,baik yang bersifat internal maupun eksternal.

Dakwah merupakan suatu aktivitas seorang muslim untuk menyebarkan ajaran Islam ke muka bumi yang penyampaiannya diwajibkan kepada setiap muslim, yang mukalaf sesuai dengan kadar kemampuannya. Islam adalah agama dakwah artinya agama yang selalu mendorong pemeluknya untuk senantiasa aktif melakukan kegiatan dakwah. Implikasi dari pernyataan Islam sebagai agama dakwah menuntut ummatnya agar selalu menyampaikan dakwah, karena kegiatan ini merupakan aktivitas yang tidak pernah usai selama kehidupan dunia masih berlangsung dan akan terus melekat dalam situasi dan kondisi apa pun bentuk dan coraknya. ${ }^{1}$

Sebagaimana yang termaktub dalam Al-Qur'an, Surat AliImran:

"Dan hendaklah ada diantara kamu segolongan umat yang menyeru kepada kebajikan, menyuruh kepada yang ma"ruf dan mencegah dari yang mungkar, dan merekalah orang-orang yang beruntung." (QS. Al Imran :104)

Jalaluddin Rakhmat memberikan definisi tersendiri mengenai kata "dakwah", walaupun definisi dari Jalal itu sendiri tidak jauh berbeda

${ }^{1}$ MunzierSupartadanHarjaniHefni.MetodeDakwah. Jakarta :Prenadamedia Group. 2015. hlm : 5. 
dengan definisi yang sudah ada. Dakwah menurut Jalal adalah setiap panggilan atau ajakan yang membawa orang ke jalan kebenaran. Mengajak manusia menuju kesaksian itu adalah atas dasar keterangan, keyakinan dan bukti aqli dan syar'i. ${ }^{2}$ Bagi Jalal, semakin berkembangnya pola hidup manusia saat ini telah menyebabkan manusia disibukkan dengan tanggung jawab terhadap dirinya dan melupakan tanggung jawabnya kepada keluarga, kaum, atau kampung halamannya. ${ }^{3}$ Dengan demikian masyarakat di era sekarang mulai tidak memperhatikan lingkungan di sekitar. Sehingga membutuhkan penyadaran atas hal demikian. Dakwah yang diperlukan adalah yang mendorong pelaksanaan dan peningkatan kehidupan sosial, dikarenakan pada lapisan bawah (masyarakat awam) khususnya kebutuhan yang semakin mendesak adalah "melepaskan diri dari himpitan hidup" yang semakin berat sehingga diperlukan proses diversifikasi atau penganekaragaman dalam kegiatan dakwah yang terus menerus. ${ }^{4}$

Dakwah disebut juga komunikasi Islam, memiliki beberapa unsur seperti subjek dakwah ( $d^{\prime} i$ ), objek dakwah (mad'u), materi dakwah (maddah), media dakwah (thoriqoh), metode dakwah (wasilah) dan tujuan dakwah. Semua unsur ini merupakan konsep yang harus diuji melalui riset-riset yang lebih empirik. Pijakan dakwah adalah isyarat - isyarat etik-normatif dari Qur'an dan Hadits. ${ }^{5}$ Aktifitas dakwah dikatakan berjalan secara efektif bilamana apa yang menjadi tujuan benar-benar dapat dicapai. Strategi yang didukung dengan metode yang bagus dan pelaksanaan program yang akurat, akan menjadikan aktifitas dakwah menjadi matang dan berorientasi jelas dimana cita-cita dan tujuan telah jelas direncanakan. Karena tujuan dan cita-cita yang jelas HIm : 114.

2Jalaluddin Rakhmat. Islam Alternatif Ceramah-Ceramah di Kampus. Bandung : Mizan. 1986.

33alaluddin Rakhmat. Islam Aktual. Bandung : Mizan. 1992. Hlm : 155.

4 Skripsi Ade Hidayat. Konsep Dakwah Menurut Jalaludin Rahmat (Studi Terhadap PrinsipPrinsip Komunikasi Dalam Islam). Hlm : 4.

${ }^{5}$ AcepAripudin. PengembanganMetodeDakwah:

ResponDa'iTerhadapDinamikaKehidupanBeragama di Kaki Ciremai. Jakarta: RajawaliPers. 2011. $\mathrm{HIm}: 1$. 
dan realistis pastiakan mendorong dakwah untuk mengikuti arah yang telah terencana. Untuk ituperlu sebuah metode atau cara yang sistematis yang digunakan untuk menyampaikan materi atau pesan dakwah kepada mad'u.

Metode dakwah adalah jalan atau cara-cara untuk mencapai tujuan dakwah yang dilaksanakan secara efektif dan efisien. ${ }^{6}$ Berkaitan dengan persoalan-persoalan dakwah, penulis menyadari sebenarnya sudah banyak pemikir dakwah yang mencoba memecahkannya, baik pada tingkat wacana maupun praktis. Salah satunya adalah Jalaluddin Rakhmat. Jalaluddin Rakhmat atau lebih akrab disapa dengan panggilan Kang Jalal adalah satu di antara cendekiawan Muslim Indonesia yang memiliki komitmen dengan dunia dakwah. Kang Jalal berhasil mendiagnosis hampir secara komprehensif persoalan masyarakat modern dan kemudian memberikan rekomendasi kepada para da'i apa yang mesti dilakukannya. Menurut Jalaluddin Rakhmat, untuk melakukan kegiatan dakwah diperlukan keahlian dalam penyampaian nilai-nilai dakwah yang terkandung dalam ajaran agama Islam, baik melalui lisan maupun perbuatan, yang itu semua memerlukan sebuah alat untuk mengkomunikasikan apa yang ada dalam Islam.

Sesungguhnya esensi dakwah terletak pada usaha pencegahan dan penanganan penyakit-penyakit masyarakat yang bersifat psikis dengan cara mengajak, memotivasi, merangsang serta membimbing individu agar sejahtera jiwa dan raganya, sehingga mereka dapat menerima ajaran agama dengan penuh kesadaran.Untuk mewujudkan cita-cita dalam memperkenalkan dan mengembangkan dakwah tersebut, seorang da"i harus memiliki sifat-sifat asasi dan ia harus berpegang pada uslub atau cara yang benar dan baik dalam melaksanakan dakwahnya. ${ }^{6}$

Begitu pun dengan konseling dalam Islam adalah salah satu dari berbagai tugas manusia dalam membina dan membentuk manusia yang 
ideal. Konseling pun akhirnya menjadi satu kewajiban bagi setiap individu muslim, khususnya para alim ulama. ${ }^{7}$ Esensi konseling dengan pendekatan Islam ini adalah "Upaya membantu individu belajar mengembangkan fitrah atau kembali kepada fitrah". Maka dalam membantu individu pun dilakukan sesuai dengan cara-cara yang diajarkan Allah dalam Al-Qur'an surat An-Nahl : 125 yaitu (a) dengan cara yang terbaik, dengan rujukan yang paling benar atau bebas dari kesalahan, dan mendatangkan manfaat atau kebaikan yang paling besar (bil-hikmah), (b) dengan ucapan-ucapan yang menyentuh hati dan mengantar kepada kebaikan (al mau'idhah al-khasanah); agar ucapan itu bisa menyentuh hati maka perlu keteladanan dari yang menyampaikannya, dan (c) (mujadalah) jika perlu dilakukan diskusi dengan cara yang baik-baik, yaitu dengan argumen-argumen yang bisa diterima. ${ }^{8}$

Penulis berusaha untuk menemukan atau paling tidak mengungkapkan metode dakwah menurut Jalaluddin Rakhmat. Hal demikian untuk mengungkapkan sisi perbedaan antara metode dakwah yang telah ada dengan pemikiran Jalaluddin Rakhmat.Dakwah bukan saja harus memberikan wawasan keislaman yang lebih luas (lebih kognitif), bukan hanya memberikan hiburan untuk melupakan persoalan dan meredakan tekanan psikologis. Dakwah juga harus membantu orang-orang modern dalam memahami dirinya. Para da'i harus mampu membimbing umat untuk memahami realitas, memaksimalkan potensi yang mereka miliki dan akhirnya mengembangkan kepribadian mereka. ${ }^{9}$ Bahwasanya esensi dakwah terletak pada usaha pencegahan dan penanganan penyakit-penyakit masyarakat yang bersifat psikis. Sedangkan tujuan bimbingan dan konseling Islami adalah agar individu menjadi muslim yang bahagia dunia dan akhirat.

${ }^{7}$ Musfir bin Said Az-Zahrani. Konseling Terapi. Jakarta : Gema Insani. 2005. HIm :16.

${ }^{8}$ Anwar Sutoyo. BimbingandanKonselingIslami (TeoridanPraktik).Semarang :PustakaPelajar. 2014. Hlm :218-219.

9Jalaluddin Rakhmat. Islam Aktual. Bandung : Mizan. 1992. Hlm : 70. 


\section{B. TEORI KONSEP METODE DAKWAH DAN BIMBINGAN KONSELING ISLAM}

\section{Metode Dakwah}

Ditinjau dari segi etimologis (bahasa) da'wah berarti : panggilan, seruan, atau ajakan. Bentuk perkataan tersebut dalam bahasa Arab disebut mashdar. Sedang bentuk kata kerja atau fi'ilnya adalah $d a^{\prime} a$-yad'u yang berarti memanggil, menyeru atau mengajak. Selain kata "dakwah", Al-Qur'an juga menyebutkan kata yang memiliki pengertian hampir sama dengan "dakwah", yakni kata "tabligh" yang berarti penyampaian, dan "bayan" yang berarti penjelasan. ${ }^{10}$ Pengertian metode menurut bahasa metode berasal dari bahasa Yunani methodos yang merupakan kombinasi kata meta (melalui) dan hodos (jalan), dalam bahasa Inggris metode berarti method yang berarti cara. Metode dalam bahasa Jerman methodicay artinya jalan, sedangkan dalam bahasa Arab metode disebut thariq ${ }^{11}$. Sedangkan pengertian metode secara istilah adalah jalan yang kita lalui untuk mencapai tujuan.

Metode adalah cara yang sistematis dan terartur untuk pelaksanaan sesuatu atau cara kerja. Adapun menurut Saerozi metode dakwah adalah cara-cara yang dipergunakan oleh seorang dai untuk menyampaikan materi dakwah atau serentetan kegiatan untuk mencapai tujuan tertentu. ${ }^{12}$ Dalam ilmu komunikasi, metode dakwah ini lebih dikenal sebagai approach, yaitu cara-cara yang dilakukan oleh seorang dai atau komunikator untuk mencapai suatu tujuan tertentu atas dasar hikmah dan kasih sayang.

Metode dakwah juga merupakan cara-cara sistematis yang menjelaskan arah strategis dakwah yang telah ditetapkan. Ia bagian dari strategi dakwah. Karena menjadi strategi dakwah yang masih

${ }^{10}$ Awaludin Pimay. Metodologi Dakwah Kajian Teoritis dari Khazanah Al-Qur'an. Semarang : Rasail. 2006. Hlm : 2.

${ }^{11}$ Wahidin Saputra. Pengantar Ilmu Dakwah. Jakarta : PT Raja Grafindo Persada. 2011. Hlm: 242

${ }^{12}$ Saerozi. Ilmu Dakwah. Yogyakarta : Ombak. 2013. Hlm :40-41. 
berupa konseptual, metode dakwah bersifat lebih konkret dan praktis. Ia harus dapat dilaksanakan dengan mudah. Arah metode dakwah tidak hanya meningkatkan efektifitas dakwah, melainkan pula bisa menghilangkan hambatan-hambatan dakwah. Dengan kata lain, pendekatan dakwah harus bertumpu pada suatu pandangan human oriented menempatkan penghargaan yang mulia atas diri manusia. $^{13}$

Landasan umum bentuk metode dakwah adalah Al-Qur'an, terutama dalam QS. An-Nahl : 125 yang dijelaskan bahwa ada tiga metode dakwah yang disesuaikan dengan kondisi objek dakwah, yaitu hikmah, maw'izdhah al-Hasanah dan mujadalah :

"Serulah (manusia) kepada jalan Tuhan-mu dengan hikmahdan pelajaran yang baik dan bantahlah mereka dengan cara yang baik. Sesungguhnya Tuhanmu Dialah yang lebih mengetahui tentang siapa yang tersesat dari jalan-Nya dan Dialah yang lebih mengetahui orang-orang yang mendapat petunjuk. (QS. An-Nahl : 125)

a) Metode Hikmah

Kata hikmah, kerap diterjemahkan dalam pengertian bijaksana, yaitu suatu pendekatan sedemikian rupa sehingga pihak objek dakwah mampu melaksanakan apa yang didakwahkan atas kemauannya sendiri, tanpa ada paksaan, konflik, maupun rasa tertekan. Menurut bahasa komunikasi disebut sebagai frame of reference, field of reference, field of experience, yaitu situasi total yang mempengaruhi sikap pihak komunikan (objek dakwah).

Menurut Syekh Imam Nawawi al-Bantani, hikmah adalah alHujjah al-Qth'iyyah al-Mufidah li al-'Aq'id al-Yaqiniyyah yaitu argumentasi yang valid (qath'i) dan berfaedah bagi kadah-kaidah keyakinan. ${ }^{14}$ Selanjutnya, M. Abduh berpendapat bahwa hikmah adalah mengetahui rahasia dan faedah di dalam tiap-tiap hal.

${ }^{13}$ Toto Tasmara. Komunikasi Dakwah. Jakarta : Gaya Media Pratama. 1997. Hlm : 43.

14 Tata Sukayat. IlmuDakwahPerspektifFilsafatMabadi' Asyarah. Bandung :SimbiosaRekatama Media. 2015. hlm : 31. 
Hikmah juga digunakan dalam arti ucapan yang sedikit lafazh akan tetapi banyak makna ataupun diartikan meletakkan sesuatu pada tempat atau semestinya.

b) Al-Mau'idza Al-Hasanah

Secara bahasa, mau'izhah hasanah terdiri dari dua kata, yaitu mau'izhah dan hasanah. kaata mau'izhah terdiri dari kata wa'adzu ya'idzu-wa'dzan-'idzatan yang berarti nasihat, bimbingan, pendidikan dan peringatan, sementara hasanah merupakan kebaikan.Mau'izhah hasanah dapatlah diartikan sebagai ungkapan yang mengandung unsur bimbingan, pendidikan, pengajaran, kisah-kisah, berita gembira, peringatan, pesan-pesan positif (wasiat) yang bisa dijadikan pedoman dalam kehidupan agar mendapatkan kedamaian dunia dan akhirat. Bahasa dalam dakwah dengan al-mau'izhah al-hasanah, merupakan cara yang paling banyak digunakan. Dengan demikian, bahasa mempunyai peran yang sangat besar dalam mengendalikan tingkah laku manusia.

Maka perlunya pengkajian konsep Al-Qur'an tentang penggunaan tutur kata (qaul) dalam berdakwah. Konsep AlQur'an tentang bahasa atau tutur kata (qaul) dapat dijelaskan sebagai berikut :

1. Qaulan Baligha (Perkataan yang Membekas pada Jiwa)

Menurut Ishfihani perkataan yang baligh (membekas atau tajam) mempunyai dua arti :Pengertian pertama yaitu suatu perkataan dianggap baligh, manakala berkumpul padanya tiga sifat, (a)memiliki kebenaran dari sudut bahasa, (b) mempunyai kesesuaian dengan apa-apa yang dimaksudkan, dan (c) mengandung kebenaran secara substansial.

Sedangkan pengertian kedua yaitu suatu perkataan dinilai baligh jika perkataan itu membuat lawan bicara terpaksa harus mempersepsi perkataan itu sama dengan apa 
yang dimaksudkan oleh pembicara, sehingga tidak ada celah untuk mengalihkan perhatian ke permasalahan lain. ${ }^{15}$

2. Qaulan Layyina (Perkataan yang Lemah Lembut)

Dakwah qaulan layyina dapat dipahami sebagai dakwah dengan tutur kata yang lemah lembut, yakni katakata yang dirasakan oleh mad'u sebagai sentuhan yang halus tanpa menyentuh atau mengusik kepekaan perasaan. ${ }^{16}$ Dengan sentuhan yang halus itu, orang kasar pun dibuat sulit untuk mendemonstrasikan kekasarannya. Terhadap dakwah yang lembut, mad'u yang kasar pun jika menolak, penolakannya tidak diucapkan secara langsung, tapi menggunakan cara yang halus juga, sehingga masih memungkinkan ada komunikasi lagi pada kesempatan yang lain.

3. Qaulan Maysura (Perkataan yang Ringan)

Menurut bahasa Arab, term qaulan maysura berasal dari kata "yasara" yang berarti mudah, lawan dari masura yang berarti sulit. Ketika kata masyura dikatakan dengan sifat qaul, maka dapat dipahami sebagai perkataan yang mudah diterima dan pantas didengar. Dakwah dengan qaulan maysura artinya pesan yang disampaikan itu sederhana, mudah dimengerti dan dipahami secara spontan tanpa harus berpikir dua kali. ${ }^{17}$ Qaulan masyura ditujukan kepada orang-orang yang berada di bawah garis kemiskinan yang membutuhkan pertolongan, sehingga mereka jarang bisa menerima informasi yang diterimanya dengan cermat.

4. Qaulan Karima (Perkataan yang Mulia)

Menurut bahasa Arab, term karima mengandung arti kata-kata yang penuh dengan kebajikan (katsir al-khair). Jika

${ }^{15}$ Achmad Mubarok. Psikologi Dakwah. Malang : Madani Press. 2014. Hlm : 191.

${ }^{16}$ Awaludin Pimay. Metodologi Dakwah Kajian Teoritis dari Khazanah Al-Qur'an. Semarang : Rasail. 2006. hlm : 62.

17M. Munir. Metode Dakwah. Jakarta :Prenadamedia Group. 2015. Hlm : 169. 
dikaitkan dengan qaul, maka ia berarti sahlan wa layyinan, yakni perkataan yang mudah dan lembut. Inilah etika komunikasi dalam Islam, yaitu penghormatan terhadap orang tua. Berkomunikasi dengan orang lain dengan penuh rasa hormat. Dengan demikian, penggunaan qaulan kariman ini didasarkan pada prinsip pergaulan dalam Islam, yaitu menghormati yang lebih tua dan menghormati yang muda.

5. Qaulan Sadida (Perkataan yang Benar)

Menurut Ibnu Mazhur, kata sadida yang dikaitkan dengan kata qaula mempunyai makna "mengenai sasaran" (yushib al-qashad), karena itu pesan dakwah secara psikologi dapat menyentuh mad'u. Ada beberapa makna dari pengertian benar. Jika materi yang disampaikan menggunakan perkataan yang benar, baik dari segi bahasa maupun logika serta berpijak pada taqwa.

Al-Qur'an, ia berbicara "Fi anfusihim" (tentang diri mereka), dalam istilah sunnah" berkomunikasilah kamu sesuai dengan kadar akal mereka". Komunikator baru efektif bila ia menyesuaikan pesannya dengan kerangka rujukan dan media pengalaman khalayaknya, dengan kata lain komunikasi itu menuntut persiapan pesan yang cermat, keberanian dan kemampuan menghadapi sejumlah besar orang. Daya tarik pembicara bahkan sering merupakan faktor penting yang menentukan efektivitas pesan. ${ }^{18}$

6. Qaulan Ma'rufa (Perkataan yang Baik)

Menurut bahasa Arab, kata al-ma'ruf sering diartikan dengan al-khair atau al-ihsan yang diterjemahkan ke dalam bahasa Indonesia "yang baik-baik". Jadi, qaulan ma'rufa

${ }^{18}$ DeddyMuljana. IlmuKomunikasiSuatuPengantar. Bandung: Rosda, 2001. HIm : 74. 
dapat diartikan dengan perkataan atau ungkapan yang baik dan pantas. ${ }^{19}$

Dari uraian-uraian di atas dapat dikatakan bahwa dakwah bi al-mau'izhah al-hasanah atau dakwah dengan pengajaran yang baik, sebagaimana dakwah bi al-hikmah. Tidak hanya memperhatikan persoalan materi tetapi perlu juga memperhatikan kesuaian materi tersebut dengan golongan obyek dakwah. Hal demikian dengan pemilihan materi yang indah dan menyejukkan bagi para umat. Jadi, metode ini merupakan cara berdakwah dengan memberikan nasihatnasihat atau menyampaikan ajaran Islam dengan rasa kasih sayang, sehingga nasihat dan ajaran Islam yang disampaikan itu dapat menyentuh hati mereka.

\section{c) Mujadalah}

Dari segi etimologi (bahasa) lafazh mujadalah terambil dari kata "jadala" yang bermakna memintai, melilit. Apabila ditambahkan alif pada huruf jim yang mengikuti wazan Faa ala, "jaa dala" dapat bermakna berdebat, dan "mujadalah" perdebatan. Metode ini lebih populer disebut dengan metode dikusi, yaitu saling silang dalam menyampaikan dalil dalam sebuah perdebatan.

Sedangkan menurut istilah, terdapat beberapa pengertian tentang metode mujadalah :

1) Menurut al-Maraghi, mujadalah berarti berdialog dan berdiskusi agar mereka patuh dan tunduk.

2) Al-Zamahsyari mengartikan mujadalah sebagai metode yang paling bagus dalam berdialog, yaitu dengan lemah lembut, tanpa kekerasan.

${ }^{19}$ Awaludin Pimay. Metodologi Dakwah Kajian Teoritis dari Khazanah Al-Qur'an. Semarang : Rasail. 2006. hlm :64-68. 
3) M. Natsir berpendapat bahwa dakwah bi al-mujadalah bi allaty hisa ihsan dapat saja diterapkan baik kepada golongan cerdik maupub terhadap golongan awam. ${ }^{20}$

Al-Mujadalah adalah metode dakwah dengan cara bertukar pendapat yang dilakukan oleh dua pihak yang secara sinergis. Tidak adanya sebuah permusuhan dengan tujuan agar lawan menerima pendapat yang dilakukan. Antara satu dengan yang lain saling menghargai dan menghormati pendapat keduanya. Jadi, metode ini merupakan suatu metode dengan cara bertukar pikiran dan membentah dengan cara sebaikbaiknya dengan tidak memberikan tekanan-tekanan dan tidak pula menjelekkan yang menjadi mitra dakwah.

\section{Bimbingan dan Konseling Islam}

Bimbingan dan konseling, Istilah bimbingan merupakan terjemahan dari kata bahasa Inggris yaitu "guidance" yang berasal dari kata kerja to guide yang berarti menunjukkan. Pengertian bimbingan adalah menunjukkan, memberi jalan, atau menuntun orang lain ke arah tujuan yang lebih bermanfaat bagi hidupnya di masa kini dan masa datang. ${ }^{21}$ Pengertian bimbingan secara umum adalah proses pemberian bantuan yang dilakukan oleh seorang ahli kepada seorang atau beberapa orang agar mampu mengembangkan potensi (bakat, minat dan kemampuan) yang dimiliki, mengenali dirinya, mengatasi persoalan-persoalan, sehingga mereka dapat menentukan sendiri jalan hidupnya secara bertanggung jawab tanpa tergantung kepada orang lain.

Sedangkan menurut Anwar Sutoyo hakikat Bimbingan dan Konseling Islam ialah upaya untuk membantu individu belajar mengembangkan fitrah-iman dan atau kembali kepada fitrah-iman,

\footnotetext{
${ }^{20}$ Awaludin Pimay. Metodologi Dakwah Kajian Teoritis dari Khazanah Al-Qur'an. Semarang : Rasail. 2006. HIm :71-72.

${ }^{21}$ Arifin, ,PedomanPelaksanaan BimbingandanPenyuluhan Agama. Jakarta : PT. Golden Terayon Press, Jakarta. 1994. Hlm :1.
} 
dengan cara memberdayakan (enpowering) fitrah-fitrah (jasmani, rohani, nafs, dan iman) mempelajari dan melaksanakan tuntutan Allah dan rasul-Nya, agar fitrah-fitrah yang ada pada individu berkembang dan berfungsi dengan baik dan benar. Pada akhirnya diharapkan agar individu selamat dan memperoleh kebahagiaan yang sejati di dunia dan akhirat. ${ }^{22}$

Achmad Mubarok juga mengatakan bahwa bimbingan dan konseling Agama merupakan bantuan yang diberikan kepada seseorang atau sekelompok orang yang sedang mengalami kesulitan lahir batin dalam menjalankan tugas-tugas hidupnya dengan menggunakan pendekatan agama, yakni dengan membangkitkan kekuatan getaran iman di dalam dirinya untuk mendorongnya mengatasi maslah yang dihadapi.23Jadi bimbingan dan konseling Islam adalah proses pemberian bantuan terhadap individu agar mampu hidup selaras dengan ketentuan dan petunjuk Allah, sehinngga dapat mencapai kebahagiaan hidup didunia dan akhirat. Hal ini merupakan pemberian bantuan dari konselor untuk membantu klien membangkitkan ajaran agama dalam menyelesaikan segala problematika hidup sesuai agama dan keyakinan.

Tujuan yang ingin dicapai melalui bimbingan dan konseling Islami adalah agar fitrah yang dikaruniakan Allah kepada individu bisa berkembang dan berfungsi dengan baik, sehingga menjadi pribadi kaffah, dan secara bertahap mampu mengaktualisasikan apa yang diimaninya itu dalam kehidupan sehari-hari, yang tampil dalam bentuk kepatuhan terhadap hukum-hukum Allah dalam melaksanakan tugas kekhalifahan di bumi, dan ketaatan dalam beribadah dengan mematuhi segala perintah-Nya dan menjauhi

\footnotetext{
22 Anwar Sutoyo. :PustakaPelajar. 2014. Hlm : 207.

(TeoridanPraktik).Semarang

${ }^{23}$ Achmad Mubarok. Al Irsyad an Nafsiy Konseling Agama Teori dan Kasus. Jakarta : Bina Rena Pariwara. 2004. Hlm : 4-5.
} 
segala larangannya. ${ }^{24}$ Secara umum tujuan konseling yang dikemukakan di atas dapat disederhanakan pada empat hal sebagaimana pendapat Shetzer dan Stone, di mana seorang konselor bertugas untuk membantu klien mencapai kesehatan mental yang positif seperti lebih tenang, tidak stress, memaknai ujian dengan lebih positif.

\section{Metode Dakwah dan Implementasinya Dalam Bimbingan dan Konseling Islam (BKI)}

Dakwah mengandung pengertian sebagai suatu kegiatan ajakan baik dalam bentuk lisan, tulisan, tingkah laku dan sebagainya yang dilakukan secara sadar dan berencana dalam usaha mempengaruhi orang lain baik secara individual maupun secara kelompok agar timbul dalam diri manusia suatu pengertian, kesadaran, sikap, penghayatan serta pengamalan terhadap ajaran agama sebagai message yang disampaikan kepada manusia dengan tanpa adanya unsur-unsur paksaan. Dengan demikian, maka esensi dakwah adalah terletak pada ajakan, dorongan/motivasi, rangsangan serta bimbingan terhadap orang lain untuk menerima ajaran agama dengan penuh kesadaran demi untuk kepentingan pribadinya sendiri, bukan untuk kepentingan da'i. ${ }^{25}$

Jika dakwah memiliki beberapa komponen, yaitu: da'i, mad'u, materi, metode maupun media, maka dalam praktik bimbingan konseling Islam hanya terdiri dari 2 komponen yaitu konselor, (sebagai orang yang melakukan bimbingan) dan klien sebagai orang yang memerlukan bantuan bimbingan (orang yang bermasalah). Dalam konteks ini, bimbingan konseling Islam diperlukan untuk berdakwah kepada orang-orang (mad'u) yang sedang mengalami problem kejiwaan, yakni membantu mereka agar dapat kembali menemukan

24 Anwar Sutoyo. BimbingandanKonselingIslami (TeoridanPraktik).Semarang :PustakaPelajar. 2014. Hlm : 207.

${ }^{25}$ Arifin. Psikologi DakwahSuatuPengantar. Jakarta: BumiAksara. 1993. Hlm : 6. 
dirinya dan dengan potensi getaran imannya dapat mengatasi kesulitan yang dihadapi. ${ }^{26}$

Studi dalam psikologi mengatakan bahwa manusia dikategorikan dalam dua dimensi pokok, yaitu dimensi phisik dan dimensi psikis. Dimensi phisik adalah dimensi yang berhubungan dengan aspek somatic atau genetika biologis yang membentuk perilaku tertentu sedangkan dimensi psikis adalah dimensi yang berhubungan dengan aspek-aspek kejiwaan. Al-Qur'an sebagai sumber ajaran agama Islam ternyata telah meletakkan konsepsi psikologis manusia yang sangat universal dimana dimensi kerohaniaan merupakan dimensi yang paling mendasar bagi keberadaan manusia. Tanpa dimensi ruhaniah, manusia tidak akan bisa berbuat apa-apa, hanya seonggok daging dan tulang yang tidak mampu menggerakkan organ tubuhnya sendiri. Dimensi ruhaniah merupakan dimensi yang dijelaskan secara tersendiri dalam AlQur'an yang secara garis besar elemenelemennya terdiri dari an-nafs (potensi jiwa), al-aql (potensi intelektual) dan alqolb (potensi ruhaniah). ${ }^{27}$

Metode bimbingan dan konseling dalam dakwah diperlukan mengingat banyaknya masalah yang terkait dengan keimanan dan pengamalan keagamaan yang tidak bisa diselesaikan dengan metode ceramah ataupun diskusi. Ada sejumlah masalah yang harus diselesaikan secara khusus, secara individual dan dengan tatap muka antara pendakwah dan mitra dakwah. Hal semacam ini membutuhkan pendakwah (konselor) tempat ia mencurahkan perasaannya, dan memperoleh kehangatan persahabatan serta kesejukan nasehat darinya. ${ }^{28}$

\footnotetext{
${ }^{26}$ Achmad Mubarok. Al Irsyad an Nafsiy Konseling Agama Teori dan Kasus. Jakarta : Bina Rena Pariwara. 2004. HIm : 19

${ }^{27}$ Machasin. PsikologiDakwah:SuatuPengantarStudi. Semarang: KaryaAbadi Jaya. 2015. HIm $: 44$.

${ }^{28}$ Moh. Ali Aziz. Ilmu Dakwah. Surabaya : Kencana. 2008. Hlm : 373.
} 


\section{Analisis Metode Dakwah Menurut Jalaluddin Rakhmat Dan Implementasinya Dalam Bimbingan Dan Konseling Islam}

\section{Analisis Metode Dakwah Menurut Jalaluddin Rakhmat}

Islam sebagai ajaran Ilahiyah yang berisi tata nilai kehidupan hanya akan menjadi sebuah konsep yang melangit jika tidak teraplikasikan dalam kehidupan sehari-hari. Masyarakat akan tenggelam dalam kesesatan dan tetap dalam kegelapan jika tidak tersinari oleh cahaya keislaman. Manusia akan hidup dalam kebingungan jika hidup tanpa pegangan yang kuat dengan ajaran Tuhan.Maka dakwah sebagai suatu ikhtiar untuk menyebarkan ajaran Islam di tengah masyarakat mutlak diperlukan. Tujuanya, agar tercipta individu, keluarga dan masyarakat yang menjadikan Islam sebagai pola pikir (way of thinking) dan pola hidup (way of life) agar tercapai kehidupan bahagia dunia dan akhirat.Dakwah Islam adalah dakwah yang bertujuan untuk memancing dan mengarahkan potensi fitri manusia agar eksistensi mereka punya makna di depan Tuhan dan sejarah. ${ }^{29}$

Metode-metode tersebut, bagi Jalaluddin Rakhmat saat ini bukanlah sebuah metode dakwah yang sudah cukup mengena. Akan tetapi masih diperlukan adanya pembaharuan-pembaharuan. Hal ini menjadi isyarat bahwa metode bukanlah sesuatu yang baku dan tak boleh berubah. Ia dapat berubah setiap saat, tergantung tantangan realitas yang melingkupinya. Namun demikian secara esensial AlQuran telah memberikan landasan yang baku berkenaan dengan prinsip-prinsip yang harus dibangun dalam berbagai ragam metode dakwah. Menurut Jalaluddin paling tidak terdapat tiga metode yang bisa digunakan dalam berdakwah. Ketiga hal ini telah disebutkan secara gamblang dalam An-Nahl: 125, yakni: dakwah dengan hikmah (bi al-hikmah), mau'idzah hasanah, dan dakwah dengan diskusi yang baik (mujadalah billati hiya ahsan).

${ }^{29}$ Ahmad Syafi'i Ma'arif. Membumikan Islam . Yogyakarta : Pustaka Pelajar. 1995. Hlm : 109. 
a. Metode dakwah hikmah (bi al-hikmah)

Hikmah adalah bekal da'i menuju sukses. Karunia Allah yang diberikan kepada orang yang mendapatkan hikmah akan berimbas kepada para mad'u nya, sehingga mereka termotivasi untuk megubah diri dan mengamalkan apa yang disampaiakan da'i kepada mereka. Tidak semua orang mampu meraih hikmah, sebab Allah hanya memberikannya untuk orang yang layak mendapatkannya. Barang siapa mendapatkannya, maka dia memperoleh karunia besar dari Allah. Allah berfirman:

"Allah menganugerahkan Al Hikmah (kefahaman yang dalam tentang Al Quran dan As Sunnah) kepada siapa yang dikehendakiNya, dan Barangsiapa yang dianugerahi hikmah, ia benar-benar telah dianugerahi karunia yang banyak. dan hanya orang-orang yang berakallah yang dapat mengambil pelajaran (dari firman Allah)".

Ayat tersebut mengisyaratkan betapa pentingnya menjadikan hikmah sebagai sifat dan bagian yang menyatu dalam metode dakwah dan betapa perlunya dakwah mengikuti langkah-langkah yang mengandung hikmah. Ayat tersebut seolah-olah menunjukkan metode dakwah praktis kepada juru dakwah yang mengandung arti mengajak manusia untuk menerima dan mengikuti petunjuk agama dan akidah yang benar.

Sebagaimana menurut Jalaluddin Rakhmat dengan cara demikian, da'i bisa memilih dan memilah hal mana saja yang tidak perlu dan perlu disampaikan kepada masyarakat. Tujuannya jelas, yakni agar ajaran Islam dan kebenaran yang inheren di dalamnya bisa mudah dipahami orang lain. Menurut Jalaluddin, seorang da'i (atau komunikator) mungkin tidak akan bisa memahami secara holistik-komprehensif karakter, nilai, pendidikan, atau tata norma pada suatu masyarakat. Namun setidaknya sebagai seorang 
komunikator yang hendak menyampaikan pesan (yang efektif), ia hendaknya memahami hal-hal tersebut meskipun sedikit.

b. Metode dakwah mau'idzah hasanah

Mau'idzah hasanah, berarti harus yang bisa menembus hati manusia dengan lembut dan diserap oleh hati nurani dengan halus. Bukan dengan bentakan dan kekerasan tanpa ada maksud yang jelas. Begitu pula tidak dengan cara memberikan kesalahankesalahan yang kadang terjadi tanpa disadari atau lantaran ingin bermaksud baik. Karena kelembutan dalam memberikan nasehat akan lebih banyak memberikan dampak positif dalam prakteknya.

Mau'idzah hasanah adalah ucapan yang berisi nasihat-nasihat yang baik dimana ia dapat bermanfaat bagi orang yang mendengarkannya, atau menurut penafsiran, mau'idhah hasanah adalah argument-argumen yang memuaskan sehingga pihak yang mendengarkan dapat membenarkan apa yang disampaikan oleh pembawa argumen itu. Sedangkan diskusi dengan cara yang baik adalah berdiskusi dengan cara yang paling baik dari cara-cara berdiskusi yang ada. ${ }^{30}$

Mau'idzah hasanah merupakan suatu ajakan ke atau penyebarluasan nilai-nilai keagamaan dengan pendekatan komunikasi verbal melalui lisan seperti ceramah atau pidato. Dalam hal ini, komunikator mengarahkan pada pemberian faktafakta konkret atas kebenaran Islam, kemudian direfleksikan pada makna yang substansial dan spiritual. Artinya, mereka mau meningkatkan kualitas keberagamaan mereka. ${ }^{31}$

Hal tersebut senada yang dikemukakan oleh Jalaluddin Rakhmat bahwa seruan dan ucapan yang baik yang dikumadangkan da'i berpotensi membangkitkan spirit kebaikan yang inhern dalam diri manusia. Dakwah Islam harus ditujukan 121-122.

${ }^{30}$ Ali Mustafa Yaqub. SejarahdanMetodeDakwahNabi. Jakarta : PustakaFirdaus. 2000. HIm :

31BambangSaifulMa'arif. KomunikasiDakwah: ParadigmauntukAksi. Bandung: SimbiosaRekatama Media. 2010. Hlm : 57. 
untuk membangkitkan potensi-potensi baik yang ada pada diri terdidik, dan mengurangi potensinya yang jelek. Dalam konteks ini, Jalaluddin membedakan dakwah yang mengarah pada otak dengan dakwah yang menyentuh hati. Penelitian komunikasi menunjukan bahwa perubahan sikap lebih cepat terjadi dengan imbauan (appeals) emosional. Tetapi dalam jangka yang lama, imbauan rasional memberikan pengaruh yang lebih kuat dan stabil.

c. Metode dakwah dengan diskusi yang baik (mujadalah billati hiya ahsan).

Mujadalah billati hiya ahsan merupakan upaya dakwah melalui bantahan, diskusi, atau berdebat dengan cara yang terbaik, sopan, santun, saling menghargai, dan tidak arogan.Menurut Jalaluddin Rakhmat, dalam kondisi tertentu dakwah ini menjadi begitu penting karena kebenaran yang disampaikan seorang pendakwah terkadang tidak dengan sendirinya menjadi jelas, kalau malah mungkin menjadi biasa. Dari itulah dibutuhkan wahana yang memungkinkan terciptanya komunikasi timbal balik yang bertujuan menggali dan menemukan kebenaran. Di samping itu, pesan yang disampaikan da'i kepada mad'u pun akan lebih bisa efektif dan mengenai sasaran, karena ia terlibat langsung dalam proses penemuan kebenaran.

Prinsip metode ini ditujukan sebagai reaksi alternatif dalam menjawab tantangan respon negatif dari mad'u, khususnya bagi sasaran yang menolak, tidak peduli, atau bahkan melecehkan seruan. Walaupun dalam aplikasi metode ini ada watak dan suasana yang khas, yakni bersifat terbuka atau transpran, konfrontatif, dan reaksioner, juru dakwah harus tetap memegang teguh prinsip-prinsip umum dari watak dan karateristik dakwah itu sendiri yaitu:

a) Menghargai kebebasan dan hak asasi tiap-tiap individu. 
b) Menghindari kesulitan dan kepicikan.

c) Bertahap, terprogram, dan sistematis.

Hal yang membedakan metode dakwah menurut pakar dakwah lain dengan Jalaluddin Rakhmat adalah dalam meletakkan pengelompokannya. Jalaluddin Rakhmat lebih mengedepankan sisi komunikasi dalam metode dakwah. Hal demikian sebagaimana sudah dijelaskan di atas bahwa menurut kang Jalal metode dakwah yaitu terdiri dari hikmah, mujadalah, dan bil lati hiya ahsan. Untuk mencapai tiga hal tersebut dapat dilakukan dengan lima prinsip komunikasi dalam Islam, yaitu qaulan sadidan, qaulan maysura, qaulan karima, qaulan layyina, qaulan baligha, dan qaulan marifa. Prinsip ini haruslah sesuai dengan tempat waktu dan keadaan manusia penerima dakwah. Karena bagaimanapun juga keadaan manusia satu sama lainnya berbeda dari banyak hal. Sehingga apa yang menjadi tujuan dakwah dapat terlaksana sesuai yang diinginkan, yaitu mewujudkan manusia yang hidupnya berlandaskan ajaran agama untuk bekal kehidupan di akherat dan mengembalikan manusia kepada fitrahnya.

\section{Implementasi Metode Dakwah Menurut Jalaluddin Rakhmat dalam Bimbingan dan Konseling Islam}

Istilah bimbingan dan konseling Islam dalam bingkai ilmu dakwah adalah Irsyad Islam. Irsyad Islam berarti proses pemberian bantuan terhadap diri sendiri (Irsyad Nafisah), Individu (Irsyad Fardiyah), atau kelompok kecil (Irsyad Fi'ah Qalilah) agar dapat keluar dari berbagai kesulitan untuk mewujudkan kehidupan pribadi, individu, kelompok yang salam, hasanah, thayibah, dan memperoleh ridha Allah dan dunia akhirat. ${ }^{32}$ Bimbingan dan konseling dan dakwah memiliki tujuan yang sama yaitu memberikan bimbingan kepada umat

32Isep Zainal Arifin. Bimbingan Penyuluhan Islam Pengembangan Dakwah Melalui Psikoterapi Islam. Jakarta : Rajawali Press. 2009. Hlm : 8. 
untuk betul-betul mencapai dan melaksanakan keseimbangan hidup dunia dan akhirat.

Pada dasarnya dakwah merupakan proses komunikasi dalam rangka mengembangkan ajaran Islam, dalam arti mengajak orang untuk menganut agama Islam. Dalam istilah "mengajak" tersebut, sudah tentu selalu terkandung makna mempengaruhi orang lain agar orang lain itu mau dan mampu mengubah sikap, sifat, pendapat, dan perilaku sesuai dengan apa yang dikendaki orang yang mengajaknya. Dalam konteks dakwah para $d a^{\prime} i$ akan selalu berusaha mempengaruhi mad'u-nya. ${ }^{33}$ Begitu pula dalam bimbingan dan konseling komunikasi dapat menentukan bagaimana orang berpersepsi terhadap diri kita, karena kita lebih banyak menghabiskan waktu untuk berkomunikasi daripada melakukan kegiatan aktivitas lainnya. ${ }^{34}$

Metode bimbingan dan konseling dalam dakwah diperlukan mengingat banyaknya masalah yang terkait dengan keimanan dan pengamalan keagamaan yang tidak bisa diselesaikan dengan metode ceramah ataupun diskusi. Ada sejumlah masalah yang harus diselesaikan secara khusus, secara individual dan dengan tatap muka antara pendakwah dan mitra dakwah. Hal semacam ini membutuhkan pendakwah (konselor) tempat ia mencurahkan perasaannya, dan memperoleh kehangatan persahabatan serta kesejukan nasehat darinya. ${ }^{35}$

Implementasi metode dakwah menurut jalaluddin Rakhmat dalam Bimbingan dan Konseling Islam yaitu:

a). Al-Hikmah

Al-Hikmah merupakan sebuah pedoman, penuntun, dan pembimbing bagi konselor dalam memberikan bantuan pada konseli agar mampu mengembangkan eksistensi dirinya sehingga mampu

\footnotetext{
33Kustadi Suhandang. Ilmu Dakwah: Perspektif Komunikasi. Bandung : PT Remaja Rosdakarya. 2013. Hlm : 24.

${ }^{34}$ Widayat Mintarsih. Konseling Lintas Budaya. Semarang : CV Karya Abadi Jaya. 2015. Hlm : 75-76.

${ }^{35}$ Moh. Ali Aziz. Ilmu Dakwah. Surabaya : Kencana. 2008. Hlm: 373.
} 
menemukan jati diri dan citra dirinya serta dapat menyelesaikan atau mengatasi berbagai masalah yang dihadapi secara mandiri. Ciri khas teori atau metode al-Hikmah ini adalah; adanya pertolongan dari Allah, diagnosa menggunakan metode ilham dan kasysyaf, adanya keteladanan konselor, dan alat terapi yang dilaukan dengan nasihat, doa, dan ayat-ayat Al-Qur'an, serta biasanya dilakukan pada terapi yang berat dimana individu dalam kondisi yang tidak mandiri. ${ }^{36}$

Al-hikmah dapat diterapkan dalam serangkaian proses konseling. Misalnya dalam tahap awal konseling di mana dalam proses ini bertujuan untuk mendefinisikan masalah. Pada tahap ini konselor membantu konseli untuk menedefinisikan permasalahan yang dihadapi. Definisi yang dimaksud adalah dengan mengurai perasaan yang dialami, menelusuri sebab dan akar permasalahan yang dihadapi serta mengeksplorasi berbagai perasaan lain yang tengah bergejolak pada diri konseli. Pada tahap ini konselor dapat menggunakan teknik-teknik attending, empati, bertanya, memulai pembicaraan, eksplorasi dan refleksi. Di mana dalam proses ini berusaha untuk memahami suatu permasalahan klien dengan cara yang baik. Dengan demikian

\section{b). Mau'idzah hasanah}

Mau'idzah hasanah dilakukan dengan penanaman moral dan etika (budi pekerti mulia) seperti kesabaran, keberanian, menepati janji, welas asih, hingga kehormatan diri, serta menjelaskan efek dan manfatnya dalam kehidupan bermasyarakat, disamping menjauhkan mereka dari perangai-perangai tercela yang dapat menghancurkan kehidupannya. Mau'idzah hasanah dalam bimbingan dan konseling merupakan teknik yang bersifat lahir yang dapat dilihat, didengar atau dirasakan oleh klien, yaitu dengan bentuk nasehat. Teknik ini dapat dilakukan konselor pada pelaksanaan bimbingan dan 
konseling baik yang bersifat individu ataupun kelompok. Maksudnya dalam konseling, konselor lebih banyak menggunakan lisan, yaitu berupa pertanyaan-pertanyaan yang harus dijawab oleh klien dengan baik, jujur dan benar.

Mau'idzah hasanah dalam bimbingan dan konseling merupakan teknik yang bersifat lahir yang dapat dilihat, didengar atau dirasakan oleh klien, yaitu dengan bentuk nasehat. Teknik ini dapat dilakukan konselor pada pelaksanaan bimbingan dan konseling baik yang bersifat individu ataupun kelompok. Maksudnya dalam konseling, konselor lebih banyak menggunakan lisan, yaitu berupa pertanyaan-pertanyaan yang harus dijawab oleh klien dengan baik, jujur dan benar. Agar konselor bisa mendapatkan jawaban-jawaban dan pertanyaan-pertanyaan yang jujur dan terbuka dari klien, maka kalimat-kalimat yang dilontarkan konselor harus berupa kata-kata yang mudah dipahami, sopan dan tidak menyinggung atau melukai hati dan perasaan klien. Demikian pula ketika memberikan nasehat hendaklah dilakukan dengan kalimat yang indah, bersahabat, menenangkan dan menyenangkan. ${ }^{37}$

Mauidzhah hasanah dapat diterapkan dalam serangkaian proses konseling. Misalnya dalam tahap pertengahan, yang merupakan tahap kerja. Di mana akan adanya nasihat-nasihat agar klien bisa menemukan berbagai alternatif atas permasalahan yang dihadapi Pada tahap ini, definisi masalah mulai jelas, perasaanperasaan tidak nyaman konseli juga sudah teridentifikasi, dan waktunya untuk mulai memikirkan langkah-langkah alternatif untuk menuju pada tindakan. Teknik yang digunakan pada tahap ini antara lain; memimpin, fokus, mengarahkan, menafsir, memperjelas, konfrontasi, mendorong, informasi, nasihat, bertanya dan menyimpulkan sementara. Dengan demikian, hal-hal tersebut dapat dilakukan dengan metode mauidzhah hasanah.

${ }^{37}$ Hamdany Bakran Adz-Dzaky. Konseling dan Psikoterapi Islam. Bandung : Rizky Press. 2000. Hlm : 212. 


\section{c). Mujadalah billati hiya ahsan}

Metode mujadalah billati hiya ahsan dapat terjadi di mana seorang konseli ingin mencari sebuah kebenaran yang dapat menyakinkan dirinya, misalnya berkaitan dengan kebingungan dalam mengambil sebuah keputusan atau pilihan terhadap sesuatu yang menurutnya sama-sama baik, padahal dalam sudut pandangan konselor terdapat keburukan dalam pilihan tersebvut yang perlu diluruskan (diperdebatkan dengan baik). ${ }^{38}$ Padahal dalam pandangan konselor hal itu dapat membahayakan perkembangan jiwa, akal fikiran, emosional, dan lingkungannya. mujadalah billati hiya ahsan dapat memberikan bimbingan dengan menggunakan bantahan atau sanggahan yang mendidik dan menentramkam.

Mujadalah billati hiya ahsan dapat diterapkan dalam serangkaian proses konseling. Misalnya dalam tahap akhir, yaitu tahap tindakan (action). Hal tersebutberusaha untuk menyakinkan klien. Pada tahap ini konseli sudah memiliki gambaran tentang berbagai alternatif solusi dan pada gilirannya memutuskan secara mandiri tindakan apa yang akan dilakukan setelah melalui berbagai pertimbangan kebaikan dan kekurangan masing-masing. Teknik yang dilakukan pada tahap ini antara lain; menyimpulkan, mendorong, merencanakan, menilai (evaluasi) dan mengakhiri sesi. Dengan demikian, hal-hal tersebut bisa dilakukan dengan metode mujadalah billati hiya ahsan.

Jalaluddin Rakhmat lebih mengedepankan sisi komunikasi dalam mengemukakan metode dakwah. Hal demikian yang sebagaimana sudah dijelaskan di atas bahwa menurut kang Jalal metode dakwah yaitu terdiri dari hikmah, mujadalah, dan bil lati hiya ahsan. Untuk mencapai tiga hal tersebut dapat dilakukan dengan lima prinsip komunikasi dalam Islam, yaitu qaulan sadidan, qaulan maysura, qaulan karima, qaulan layyina, dan qaulan baligha.

${ }^{38}$ Anila Umriana. Penerapan Ketrampilan Konseling dengan Pendekatan Islam. Semarang : CV. Karya Abadi Jaya. 2015. Hlm : 51. 
Prinsip ini haruslah sesuai dengan tempat waktu dan keadaan manusia penerima dakwah. Karena bagaimanapun juga keadaan manusia satu sama lainnya berbeda dari banyak hal. Sehingga apa yang menjadi tujuan dakwah dapat terlaksana sesuai yang diinginkan, yaitu mewujudkan manusia yang hidupnya berlandaskan ajaran agama untuk bekal kehidupan di akherat dan mengembalikan manusia kepada fitrahnya.Jadi, impementasi metode dakwah menurut Jalaluddin Rakhmat dapat dilakukan dengan cara demikian saat berlangsungnya proses bimbingan dan konseling Islam.

Selanjutnya Jalaluddin Rakhmat menggambarkan bahwa metode dakwah Islam yang lebih konstruktif niscaya memuat beberapa hal antara lain, membuat pendekatan secara intensif terhadap masyarakat yang menjadi objek dakwah, menyampaikan dakwah dengan argumentasi rasional dan kontekstual. Mengajak masyarakat secara persuasif untuk bersama-sama menjadi bagian tak terpisahkan dari sistem kemasyarakatan. Memberi terapi psikologis dan motivasi kepada masyarakat yang kehilangan kepercayaan diri untuk selalu berusaha dalam aktivitas kehidupannya. Hal demikian juga bisa diterapkan dalam bimbingan dan konseling Islam. Karena dakwah dan bimbingan konseling mempunyai tujuan yang sama yaitu untuk menyelesaikan permasalahan manusia untuk kesejahteraan dunia dan akhirat.

Penulis berpendapat bahwa metode dakwah dalam bimbingan dan konseling Islam lebih tepat diterapkan dalam bentuk kelompok maupun individu. Meskipun dalam individu lebih efektif. Ketika klien (mad'u) tidak dapat menyampaikan masalah pribadinya secara nyaman, leluasa dan terbuka di depan jama'ah yang banyak. Maka konselor (da'i) dapat menerapkan metode bimbingan dan konseling Islam, karena dalam metode bimbingan dan konseling Islam terdapat asas kerahasiaan sehingga dapat menjaga kerahasiaan masalah klien. Klien dapat bebas menyampaikan perasaan dan permasalahannya kepada konselor. 


\section{DAFTAR PUSTAKA}

Adz-Dzaky, Hamdany Bakran. Konseling dan Psikoterapi Islam. Bandung: Rizky Press. 2000.

Arifin, Isep Zainal. Bimbingan Penyuluhan Islam Pengembangan Dakwah Melalui Psikoterapi Islam. Jakarta : Rajawali Press. 2009.

Arifin. Pedoman Pelaksanaan Bimbingan dan Penyuluhan Agama, Jakarta: PT. Golden Terayon Press, Jakarta. 1994.

Aripudin, Acep. Pengembangan Metode Dakwah: Respon Da'i Terhadap Dinamika Kehidupan Beragama di Kaki Ciremai. Jakarta: Rajawali Pers. 2011.

Aziz, Moh. Ali. Ilmu Dakwah. Surabaya : Kencana. 2008.

Ma'arif, Ahmad Syafi'i. Membumikan Islam . Yogyakarta : Pustaka Pelajar. 1995.

Ma'arif, Bambang Saiful. Komunikasi Dakwah: Paradigma untuk Aksi. Bandung: Simbiosa Rekatama Media. 2010.

Machasin. Psikologi Dakwah : Suatu Pengantar Studi. Semarang: Karya Abadi Jaya. 2015.

Masyhur, Syaikh Mushthafa. Fiqih Dakwah. Jakarta: Al-I'tishom. Jilid 1. 2000.

Mintarsih, Widayat. Konseling Lintas Budaya. Semarang : CV Karya Abadi Jaya. 2015.

Mubarok, Achmad. Al Irsyad an Nafsiy Konseling Agama Teori dan Kasus. Jakarta : Bina Rena Pariwara. 2004.

Psikologi Dakwah. Malang : Madani Press. 2014.

Mulyana, Deddy. Ilmu Komunikasi Suatu Pengantar. Bandung: Rosda, 2001.

Munir, M. Metode Dakwah. Jakarta: Prenada Media, Cet ke II. 2006.

Musfir bin Said Az-Zahrani. Konseling Terapi. Jakarta : Gema Insani. 2005.

Pimay, Awaludin. Metodologi Dakwah Kajian Teoritis dari Khazanah Al-Qur'an. Semarang : Rasail. 2006.

Psikologi Dakwah Suatu Pengantar, Jakarta: Bumi Aksara. 1993.

Rakhmat, Jalaluddin. Islam Aktual. Bandung : Mizan. 1992.

Islam Alternatif Ceramah-Ceramah di Kampus. Bandung :

Mizan. 1986.

Saerozi. Ilmu Dakwah. Yogyakarta : Ombak. 2013.

Saputra, Wahidin. Pengantar Ilmu Dakwah. Jakarta : PT Raja Grafindo Persada. 2011 
Suhandang, Kustadi. Ilmu Dakwah: Perspektif Komunikasi. Bandung : PT Remaja Rosdakarya. 2013.

Sukayat, Tata. Ilmu Dakwah Perspektif Filsafat Mabadi' Asyarah. Bandung : Simbiosa Rekatama Media. 2015.

Suparta, Munzier dan Harjani Hefni. Metode Dakwah. Jakarta : Prenadamedia Group. 2015.

Sutoyo, Anwar. Bimbingan dan Konseling Islami (Teori dan Praktik). Semarang : Pustaka Pelajar. 2014.

Tasmara, Toto. Komunikasi Dakwah. Jakarta : Gaya Media Pratama. 1997.

Umriana, Anila. Penerapan Ketrampilan Konseling dengan Pendekatan Islam. Semarang : CV. Karya Abadi Jaya. 2015.

Yaqub, Ali Mustafa. Sejarah dan Metode Dakwah Nabi. Jakarta : Pustaka Firdaus. 2000.

Ade Hidayat. Konsep Dakwah Menurut Jalaludin Rahmat (Studi Terhadap PrinsipPrinsip Komunikasi Dalam Islam). 2016. 